\title{
PENGARUH KOMUNIKASI DAN ETOS KERJA TERHADAP KINERJA TENAGA PEMASAR PADA PT PRUDENTIAL LIFE ASSURANCE PRESTASI AGENCY PS-1 PEMATANGSIANTAR
}

\author{
Oleh: \\ Ista Marsara Sijabat \\ S1 Manajemen \\ Darwin Lie, Marisi Butarbutar, Andy Wijaya
}

Abstraksi

Adapun rumusan masalah penelitian ini adalah bagaimana pengaruh komunikasi dan etos kerja terhadap kinerja tenaga pemasar pada PT Prudential Life Assurance Prestasi Agency PS-1 Pematang Siantar. Metode penelitian yang digunakan dalam penulisan ini adalah penelitian kepustakaan dan penelitian lapangan. Populasinya adalah berjumlah 70 orang tenaga pemasar dan sampel dalam penelitian ini sebanyak 70 orang. Data yang digunakan adalah data dengan cara kualitatif dan data kuatitatif, dan teknik pengumpulan data dengan cara kuesioner, wawancara dan dokumentasi. Kemudian teknik analisa data menggunakan metode deskriptif kualitatif dan metode deskriptif kuantitatif.

Hasil analisa dari regresi linier berganda yaitu $\hat{\mathrm{Y}}=8,824+0,328 \mathrm{X}_{1}+0,389 \mathrm{X}_{2}$, artinya komunikasi dan etos kerja berpengaruh positif terhadap kinerja tenaga pemasar. Kekuatan hubungan ketiga variabel adalah sangat kuat, yaitu $r=0,680$. Dari koefisien determinasi dapat dijelaskan tinggi rendahnya kinerja tenaga pemasar 46,3 $\%$, dan sisanya $53,7 \%$ dijelaskan oleh faktor lainnya yang yang tidak dibahas dalam penelitian ini. Dari hasil pengolahan dan perhitungan kuesioner, penulis mendapatkan kesimpulan bahwa komunikasi dan etos kerja pada PT Prudential Life Assurance Agency PS-1 berpengaruh positif dan signifikan terhadap kepuasan konsumen. Hal ini dibuktikan melalui uji hipotesis secara simultan, dimana hasil uji $f_{\text {hitung }}(28,828)>f_{\text {tabel }}(3,13)$ dengan taraf signifikansi $0,000<$ alpha 0,05 .

Kata Kunci: Komunikasi, Etos Kerja, Kinerja Tenaga Pemasar

\section{Abstraction}

The formulation of this research problem is how the influence of communication and work ethic on the performance of marketers in PT Prudential Life Assurance Achievement Agency PS-1 Pematang Siantar. The research method used in this paper is literature research and field research. The population is 70 people marketers and the sample in this study as many as 70 people. The data used are data by qualitative and qualitative data, and data collection techniques by questionnaire, interview and documentation. Then the technique of data analysis using qualitative descriptive method and quantitative descriptive method.

The result of analysis from multiple linear regression is $\hat{Y}=8,824+0,328 \mathrm{X} 1+0,389 \mathrm{X} 2$, meaning that communication and work ethic have positive effect to marketer performance. The strength of the relationship between the three variables is very strong, ie $r=0.680$. From the coefficient of determination can be explained the high performance of market power $46.3 \%$, and the remaining $53.7 \%$ explained by other factors that are not discussed in this study. From the results of processing and calculation of the questionnaire, the authors get the conclusion that communication and work ethic at PT Prudential Life Assurance Agency PS-1 have a positive and significant impact on customer satisfaction. This is proven by hypothesis testing simultaneously, where the test result fhitung $(28,828)>$ ftabel $(3,13)$ with significance level $0,000<$ alpha 0,05 .

Keywords: Communication, Work Ethic, Performance of Marketers

\section{A. PENDAHULUAN}

\section{Latar Belakang Masalah}

Sapadia Hotel Pematangsiantar merupakan suatu perusahaan yang bergerak pada bidang pelayanan jasa penginapan. Sapadia Hotel Pematangsiantar beralamat di jalan Diponegoro No. 12 A, Kelurahan Karo, Kecamatan Siantar Selatan, Kota Pematangsiantar.

Kepuasan konsumen pada dasarnya adalah suatu keadaan dimana kebutuhan, keinginan dan harapan pengguna jasa dapat terpenuhi melalui pelayanan jasa suatu hotel. Hal tersebut menyebabkan pentingnya menjaga tingkat kepuasan konsumen demi kelangsungan suatu bisnis hotel. Kepuasan konsumen diukur melalui beberapa dimensi, seperti kualitas produk, harga, faktor emosi dan kemudahan.

Tabel 1

Jumlah Kunjungan Tamu Sapadia Hotel Pematangsiantar Periode Januari Sampai dengan April 2017

\begin{tabular}{|c|c|c|}
\hline Bulan & Target & $\begin{array}{c}\text { Total } \\
\text { Pencapaian }\end{array}$ \\
\hline Januari & $100 \%$ & $18,43 \%$ \\
\hline Februari & $100 \%$ & $10,86 \%$ \\
\hline Maret & $100 \%$ & $26,59 \%$ \\
\hline
\end{tabular}




\begin{tabular}{|c|c|c|}
\hline April & $100 \%$ & $11 \%$ \\
\hline $\begin{array}{c}\text { Rata-rata } \\
\text { Pencapaian (\%) }\end{array}$ & $\mathbf{1 0 0 \%}$ & $\mathbf{1 6 , 7 2 \%}$ \\
\hline
\end{tabular}

Sumber: hasil wawancara dengan Manajer hotel.

Tabel di atas menjelaskan bahwa pencapaian target tamu Sapadia Hotel Pematangsiantar masih belum optimal. Hal ini dapat diketahui bahwa presentase pencapaian target setiap bulannya belum mencapai angka $100 \%$, dimana pencapaian target yang diperoleh masih sebesar $16,72 \%$. Hal ini di indikasikan kepuasan konsumen yang ada di Sapadia Hotel Pematangsiantar belum optimal.

Hal ini disebabkan bahwa kenyamanan prosedur yang ada di Sapadia Hotel Pematangsiantar belum optimal dilakukan, ketika konsumen melakukan kegiatan administrasi karyawan belum dapat melayani dengan efektif dan efisien yang menyebabkan waktu tunggu konsumen menjadi lama. Faktor emosi konsumen atas pelayanan yang diberikan berdampak positif sesuai dengan citra dan merek hotel yang berkualitas baik. Harga, dengan harga produk/jasa yang cukup mahal namun dari setiap produk/jasa yang ditawarkan pihak hotel kepada konsumen masih sesuai dengan harga dan kualitasnya. Kualitas produk yang ditawarkan oleh pihak hotel sangatlah bervariasi dan didesain dengan menarik.

Adapun faktor lain yang dapat mempengaruhi kepuasan konsumen adalah kualitas pelayanan $\left(\mathrm{X}_{1}\right)$, hal ini dapat dinilai dari beberapa dimensi yaitu; bukti fisik (tangibless), kehandalan (reliability), daya tanggap (responsiveness), jaminan (assurance), dan empati (empathy). Bukti fisik (tangibles), berupa ruang tunggu yang nyaman, dan area parkir yang luas dan bersih. Kehandalan (reliability), kehandalan dan ketepatan karyawan dalam melayani konsumen belum terealisasi dengan baik ketika konsumen membutuhkan bantuan. Daya tanggap (responsiveness), mengenai respon atau kecepatan karyawan dalam melayani konsumen yang mengalami kesulitan maupun keluhan yang belum dilakukan secara optimal sesuai dengan standar perusahaan. Jaminan (assurance), kesopanan karyawan dalam melayani konsumen cukup baik karena karyawan belum dapat melakukan komunikasi yang baik dan sesuai dengan standar perusahaan. Empati (empathy), empati yang dimiliki karyawan masih kurang baik, dimana karyawan belum mampu memberikan sikap peduli secara individual bagi konsumen yang mengalami kesulitan maupun keluhan.

Selanjutnya fasilitas $\left(\mathrm{X}_{2}\right)$ juga diindikasikan memiliki pengaruh terhadap kepuasan konsumen, dimana fasilitas dapat dinilai dari beberapa dimensi yaitu; kelengkapan, kebersihan dan kerapian, kondisi dan fungsi fasilitas, kemudahan, dan kelengkapan alat. Kelengkapan, kebersihan dan kerapian yang ada di hotel sudah dilakukan dengan baik dengan pemberian kamar yang lengkap dengan fasilitas di dalamnya, kamar yang bersih dan rapi. Kondisi dan fungsi fasilitas, kondisi gedung hotel yang sangat central dan di desain dengan menarik sehingga mampu memberikan daya tarik bagi calon konsumen hotel.

Kemudahan dalam penggunaan fasilitas pada hotel belum optimal, hal ini dikarenakan bawa pihak hotel belum melengkapi fasilitas-fasilitas beserta petunjuk penggunaannya, sehingga hal ini membuat konsumen kesulitan dalam memakai fasilitas yang tersedia di hotel tersebut. Kelengkapan alat yang tersedia berupa alat penunjang keamanan konsumen dan kenyamanan konsumen disediakan dengan baik yang mengakibatkan konsumen merasa aman dan nyaman berada di lingkungan hotel.

\section{Rumusan Masalah}

a. Bagaimana gambaran kualitas pelayanan, fasilitas, dan kepuasan konsumen pada Sapadia Hotel Pematangsiantar.

b. Bagaimana pengaruh kualitas pelayanan dan fasilitas terhadap kepuasan konsumen pada Sapadia Hotel Pematangsiantar.

\section{Tujuan Penelitian}

a. Untuk mengetahui gambaran kualitas pelayanan, fasilitas, dan kepuasan konsumen pada Sapadia Hotel Pematangsiantar.

b. Untuk mengetahuipengaruh kualitas pelayanan dan fasilitas terhadap kepuasan konsumen pada Sapadia Hotel Pematangsiantar.

\section{Metode Penelitian}

Lokasi atau tempat penelitian ini dilakukan di Sapadia Hotel Pematangsiantar yang berada di Jalan Diponegoro No. 21 A, Kelurahan Karo, Kecamatan Siantar Selatan, Kota Pematangsiantar. Pada penelitian ini yang menjadi populasi adalah konsumen Sapadia Hotel Pematangsiantar sebanyak 164 orang yang diambil dari data kunjungan tamu selama bulan Januari s/d April 2017. Teknik pengambilan sampel dalam penelitian ini menggunakan rumus Slovin, sehingga diperoleh jumlah sampel dalam penelitian ini sebanyak 116 orang akan menjadi responden untuk menjawab kuesioner yang penulis sebarkan, mengingat jumlahnya lebih dari 100 (seratus) orang dan ketersediaan waktu penulis serta untuk keakuratan hasil penelitian.

Adapun Desain penelitian yang digunakan dalam penulisan skripsi ini adalah Penelitian Kepustakaan (Library Research) dan Penelitian Lapangan (Field Research). Teknik pengumpulan data yang dilakukan penulis dalam penelitian ini adalah berupa Kuesioner, Wawancara dan Dokumentasi. Adapun jenis data yang digunakan dalam penelitian ini adalah jenis data kualitatif dan data kuantitatif. Hasil data yang diperoleh dari lapangan akan dianalisis secara deskriptif baik bersifat kualitatif dan kuantitatif.

\section{B. LANDASAN TEORI}

1. Manajemen Pemasaran

Menurut Kotler \& Kevin (2007:6), pemasaran adalah salah satu fungsi organisasi dan seperangkat 
proses untuk menciptakan, mengkomunikasikan dan menyerahkan nilai kepada pelanggan dan mengelola hubungan pelanggan dengan cara yang menguntungkan organisasi dan para pemiliki sahamnya. Menurut Boyd, et. al. (2000:4), pemasaran adalah suatu proses sosial yang melibatkan kegiatan-kegiatan penting yang memungkinkan individu dan perusahaan mendapatkan apa yang mereka butuhkan dan inginkan melalui pertukaran dengan pihak lain dan untuk mengembangkan hubungan pertukaran. Menurut Kotler \& Gary (2001:16), pemasaran adalah mengelola pasar untuk menghasilkan pertukaran dan hubungan, dengan tujuan menciptakan nilai dan memuaskan kebutuhan dan keinginan.

\section{Bauran Pemasaran}

Menurut Boyd, et. al. (2000:21), bauran pemasaran adalah kombinasi dari variabel-variabel pemasaran yang dapat dikendalikan oleh manajer untuk menjalankan strategi pemasaran dalam upaya mencapai tujuan perusaaan di dalam pasar sasaran tertentu. Menurut Kotler dan Gary (2008:62), bauran pemasaran adalah kumpulan alat pemasaran taktis terkendali yang dipadukan perusahan untuk menghasilkan respons yang diinginkannnya dipasar sasaran. Menurut Lupiyoadi dan Hamdani (2006:70), bauran pemasaran (marketing mix) merupakan alat bagi pemasaran yang terdiri atas berbagai unsur suatu program pemasaran yang perlu dipertimbangkan agar implementasi strategi pemasaran dan positioning yang ditetapkan dapat berjalan sukses.

Menurut Lupiyoadi dan Hamdani (2006:70), elemen-elemen bauran pemasaran meliputi terdiri dari atas tujuh hal, yaitu:

1) Product adalah jasa seperti apa yang ingin ditawarkan.

2) Price adalah bagaimana strategi penentuan harga.

3) Promotion adalah bagaimana promosi yang harus dilakukan.

4) Place adalah bagaiman sistem penyampaian jasa yang akan diterapkan.

5) People adalah orang yang akan terlibat dalam pemberian jasa.

6) Process adalah bagaimana proses dalam operasi jasa tersebut.

7) Customer service tingkat jasa yang bagaimana yang akan diberikan kepada konsumen.

Menurut Lovelock dan Musry (2010:24),

elemen-elemen bauran pemasaran meliputi;

1) Produk (Product)

Produk adalah suatu elemen-elemen jasa inti dan tambahan. Elemen tambahan memfasilitasi dan meningkatkan penawaran produk inti.

2) Harga (Price)

Harga adalah nilai yang menjadi bagian melekat dalam pembayaran dalam mempermudah pertukaran nilai antar perusahaan dan para pelanggannya.
3) Lokasi (Place)

Lokasi adalah suatu acuan penghantaran elemen-elemen produk kepada para pelanggannya.

4) Promosi (Promotion)

Promosi adalah bagaimana sebuah perusahaan memberikan informasi kepada para pelanggan mengenai layanan mereka.

5) Proses (Process)

Proses adalah bagaimana cara perusahaan melakukan sesuatu, proses-proses pokok yang sama pentingnya dengan apa yang perusahaan lakukan. Menciptakan dan menghantarkan elemen produk membutuhkan rancangan dan implementasi proses yang efektif.

6) Lingkungan Fisik (Physical Environment)

Lingkungan fisik adalah penampilan bangunan, taman, kendaraan, perabotan interior, peralatan, seragam pegawai, tanda, materi cetak, dan berbagai isyarat lain yang memberikan bukti terwujud terhadap kualitas jasa perusahaan, memfasilitasi pelayanan dan membimbing pelanggan melaului proses pelayanan.

7) Manusia (People)

Manusia adalah orang yang akan terlibat dalam memberikan perhatian khusus, keahlian dan sikap yang positif dalam berinteraksi langsung dengan para pelanggan.

\section{Pelayanan}

Menurut Lupiyoadi \& Hamdani (2006:5), pelayanan adalah semua aktivitas ekonomi yang hasilnya bukan berbentuk produk fisik atau konstruksi, yang umumnya dihasilkan dan dikonsumsi secara bersamaan serta memberikan nilai tambah misalnya (kenyamanan, hiburan, kesenangan, atau kesehatan) konsumen. Menurut Tjiptono \& Grogerius (2005:17), pelayanan adalah aktivitas, manfaat atau kepuasan yang ditawarkan untuk dijual seperti; reparasi kendaraan bermotor, salon kecantikan, kurus keterampilan, pusat kebugaran, restoran, hotel, rumah sakit, universitas dan lain-lain. Menurut Lovelock dan Mussry (2010:16), pelayanan adalah suatu aktivitas ekonomi yang ditawarkan oleh satu pihak kepada pihak lain yang dilakukan dalam jangka waktu tertentu, dalam bentuk suatu kegiatan yang akan membawa hasil yang diinginkan kepada penerima, obyek, maupun aset-aset lainnya.

Berdasarkan pendapat para ahli di atas dapat disimpulkan bahwa pelayanan adalah segala bentuk aktivitas yang dilakukan osleh perusahaan secara langsung guna memenuhi harapan konsumen serta ketepatan penyampaian dalam mengimbangi harapan konsumen.

\section{Kualitas Pelayanan}

Menurut Lovelock (2007:96) kualitas pelayanan merupakan evaluasi kognitif jangka panjang pelanggan terhadap penyerahan jasa suatu perusahaan. Menurut Tjiptono dan Grogerius 
(2007:121), mengemukakan bahwa kualitas pelayanan sebagai ukuran seberapa bagus tingkat layanan yang diberikan mampu sesuai dengan ekspektasi pelanggan. Kualitas pelayanan diwujudkan melalui pemenuhan dan keinginan pelanggan. Menurut Zetihmal, Berry dan Parasuranman dalam Lupiyoadi dan Hamdani (2006:181), definisi kualitas pelayanan yaitu sebagai kesenjangan antara ekspektasi atau keinginan pengguna jasa dengan apa yang dirasakan oleh mereka. Berdasarkan definisi ini, maka kualitas pelayanan tidak meninjau berdasarkan sudut pandang perusahaan tetapi berdasarkan sudut pandang pengguna jasa.

Berdasarkan pendapat ahli di atas penulis dapat menyimpulkan bahwa kualitas pelayanan segala bentuk aktivitas yang dilakukan oleh perusahaan secara langsung guna memenuhi harapan konsumen. Dengan kata lain kualitas pelayanan memberikan pemenuhan kebutuhan dan keinginan konsumen ditinjau dari tingkat keunggulan kualitas jasa tersebut sehingga memenuhi kebutuhan konsumen yang diharapkan.

Menurut Parasuranman dalam Lupiyoadi dan Hamdani (2006:182), terdapat 5 (lima) dimensi kualitas pelayanan yaitu:

1) Tangibles atau bukti fisik, yaitu kemampuan perusahaan dalam menunjukkan eksistensinya kepada pihak eksternal. Yang ditunjukkan bahwa penampakan dan kemampuan sarana dan prasarana fisik perusahaan serta keadaan lingkungan sekitarnya adalah bukti nyata pelayanan yang diberikan.

2) Reability atau kehandalan, yaitu kemampuan perusahaan untuk memberikan pelayanan sesuai yang dijanjikan secara akurat dan terpercaya.

3) Responsiveness atau ketanggapan, yaitu suatu kemauan dalam memberikan pelayanan yang cepat dan tepat kepada pelanggan melalui penyampaian informasi yang jelas.

4) Assurance atau jaminan dan kepastian, yaitu suatu pengetahuan, kesopansantunan, dan kemampuan para pegawai perusahaan untuk menumbuhkan rasa percaya kepada pelanggan perusahaan. Terdiri dari beberapa komponen berupa komunikasi, kepercayaan, keamanan, kompetensi, dan kesopanan.

5) Empathy, yaitu memberikan perhatian yang tulus dan bersifat individual atau pribadi yang diberikan kepada para pelanggan dengan cara 4 . memahami keinginan pelanggan secara spesifik dari bentuk fisik produk atau jasa sampai pendistribusian yang tepat.

\section{2. $\quad$ Fasilitas}

Menurut Tjiptono (2001:184), fasilitas adalah sumber daya fisik yang harus ada sebelum suatu jasa dapat ditawarkan kepada konsumen. Fasilitas dapat 5 . pula berupa segala sesuatu yang memudahkan konsumen dalam memperoleh kepuasan. Adapun 6 . menurut Sumayang (2003:124), fasilitas didefinisikan sebagai bentuk penyediaan perlengkapan fasilitas fisik yang menawarkan kemudahan kepada konsumen untuk melakukan aktivitas-aktivitasnya sehingga kebutuhan konsumen dapat terpenuhi. Sedangkan menurut Dimyati (2002:72), berpendapat fasilitas adalah segala sesuatu yang sengaja disediakan untuk dipakai atau dipergunakan serta dinikmati oleh konsumen dan penggunaannya tidak selalu harus dibayar.

Dari beberapa pengertian di atas dapat ditarik kesimpulan bahwa fasilitas adalah suatu sumber daya fisik yang disediakan oleh pihak penyedia jasa untuk dipakai atau dipergunakan, ditempati serta dinikmati oleh konsumen untuk memudahkannya dalam melakukan aktvitasnya.

Menurut Sumayang (2003:124), terdapat beberapa unsur-unsur fasilitas antara lain:

1) Kelengkapan, kebersihan, dan kerapian fasilitas yang ditawarkan adalah keadaan fasilitas perusahaan yang dilengkapi oleh atribut yang menyertainya dan didukung dengan kebersihan dan kerapian saat konsumen menggunakan fasilitas tersebut.

2) Kondisi dan fungsi fasilitas yang ditawarkan adalah fasilitas yang berfungsi dengan baik dan tidak mengalami kerusakan.

3) Kemudahan menggunakan fasilitas yang ditawarkan kepada konsumen adalah fasilitas yang sudah tidak asing bagi konsumen sehingga dapat menggunakannya dengan mudah.

4) Kelengkapan alat yang digunakan adalah alat yang digunakan oleh konsumen sesuai dengan spesifikasinya.

\section{Kepuasan Konsumen}

Menurut Tjiptono (2002:24), kepuasan konsumen adalah respon pelanggan terhadap evaluasi ketidaksesuain yang dirasakan setelah pemakaiannya. Kemudian menurut Kotler dan Keller (2007:177), kepuasan konsumen didefinisikan sebagai bentuk perasaan senang maupun kecewa yang muncul setelah membandingkan antara kinerja produk yang dipikirkan terhadap kinerja yang diharapkan. Menurut Lovelock dan Laurence (2007:103), kepuasan konsumen adalah pelanggan yang mengalami berbagai tingkat kepuasan atau tidak kepuasan setelah mengalami masing-masing jasa sesuai untuk sejauh mana harapan mereka terpenuhi atau terlampaui.

Berdasarkan uraian di atas maka penulis dapat menyimpulkan kepuasan konsumen adalah perasaan konsumen yang dibandingkan dari hasil atau kinerja yang diharapkan. Apabila kinerja lebih rendah dari harapan konsumen, maka konsumen akan merasa kecewa karena apa yang diharapkan konsumen tidak terpuaskan, namun apabila kinerja sesuai dengan harapan, maka konsumen akan merasa puas.

Menurut Irawan (2002:37), faktor-faktor yang mempengaruhi kepuasan konsumen antara lain:

1) Kualitas Produk 
7. Pelanggan akan puas jika setelah membeli dan menggunakan produk tersebut, apabila kualitas produknya baik.

2) Harga

Kualitas produk dan harga sering kali tidak mampu menciptakan keunggulan bersaing dalam hal kepuasan pelanggan.

\section{3) Kemudahan}

Pelanggan akan merasa semakin puas jika dalam mendapatkan produk pelayanan relatif mudah, nyaman dan efisien.

4) Faktor Emosional (Emotional Factor)

Untuk beberapa produk yang berhubungan dengan gaya hidup, driver kepuasan konsumen yaitu emotional factor relatif penting.

\section{Pengaruh Kualitas Pelayanan dan}

Fasilitas Terhadap Kepuasan Konsumen

Untuk mengukur tingkat kepuasan konsumen, sangatlah perlu untuk mengetahui sejauh mana mutu kualitas jasa/pelayanan yang telah diberikan kepada konsumen sehingga hal tersebut mampu mengetahui seberapa besar tingkat kepuasan konsumen. Menurut Tjiptono dan Grogerius (2011:172), kualitas pelayanan berkaitan erat dengan kepuasan konsumen, kualitas pelayanan memberikan dorongan khusus bagi para pelanggan untuk menjalin ikatan saling menguntungkan dalam jangka panjang dengan perusahaan. Ikatan emosional semacam ini memungkinkan perusahaan untuk memahami dengan seksama harapan dan kebutuhan spesifik konsumen.

Selanjutnya penyediaan fasilitas yang dilakukan perusahaan dapat diharapkan meningkatkan kepuasan dalam diri konsumen. Dalam melihat adanya pengaruh fasilitas terhadap kepuasan konsumen, maka penulis menguraikan teori yang berhubungan yaitu menurut Tjiptono dan Grogerius (2016:94) bahwa fasilitas jasa memiliki pengaruh signifikan dalam memuaskan konsumen yang ingin mencari kenyamanan suasana.

Dari pernyataan di atas dapat disimpulkan bahwa dengan menciptakan kualitas pelayanan yang tinggi tentu akan menciptakan kepuasan yang tinggi dalam diri konsumen, dan penyediaan fasilitas yang baik tentu akan memberikan kepuasan kepada konsumen dalam menggunakan jasa hotel, sehingga dapat dikatakan bahwa kualitas pelayanan dan fasilitas secara bersama-sama berpengaruh terhadap kepuasan konsumen.

\section{PEMBAHASAN}

\section{Analisis}

\section{a. Deskriptif Kualitatif}

Analisis deskriptif dimaksudkan untuk mendapatkan gambaran atau deskripsi mengenai tanggapan dari karyawan mengenai Pengaruh kualitas pelayanan dan fasilitas terhadap kepuasan konsumen pada Sapadia Hotel Pematangsiantar. Setelah pengujian data, maka langkah selanjutnya adalah peneliti melakukan pengkajian analisis kualitatif sebagai gambaran fenomena dari variabel penelitian pada saat sekarang ini. Adapun penetapan kriteria nilai data-data jawaban dari responden tersebut dimasukkan ke dalam kelas-kelas interval, dimana penentuan intervalnya menggunakan rumus sebagai berikut:

Interval kelas $=$ Nilai Tertinggi - Nilai Terendah

$$
\begin{aligned}
= & \frac{5-1}{5} \\
= & \frac{4}{5} \\
= & 0,8
\end{aligned}
$$

Dari rumus di atas, diperoleh nilai interval kelas = 0,8 , sehingga berlaku ketentuan kategori dengan hasil sebagai berikut:

Tabel 1

Nilai Interval dan Kategori Jawaban Responden.

\begin{tabular}{|c|c|}
\hline \multicolumn{2}{|c|}{ Interpretasi Nilai r } \\
\hline Besarnya Nilai & Interpretasi \\
\hline $0,00-0,199$ & Sangat Rendah \\
\hline $0,20-0,399$ & Rendah \\
\hline $0,40-0,599$ & Sedang \\
\hline $0,60-0,799$ & Kuat \\
\hline $0,80-1000$ & Sangat Kuat \\
\hline
\end{tabular}

Sumber: Data diolah

\section{Gambaran Komunikasi pada PT Prudential} Life Assurance Prestasi Agency PS-1

\section{Pematangsiantar}

Komunikasi merupakan proses pemindahan informasi dari satu orang ke orang lain. Komunikasi dalam organisasi sangatlah penting agar tidak terjadi kesalahpahaman dalam penyampaian informasi. Komunikasi yang terdapat pada PT Prudential Life Assurance Prestasi Agency PS-1 Pematangsiantar terdiri dari tiga dimensi, diantaranya komunikasi ke bawah, komunikasi ke atas, dan komunikasi horizontal. Pada dimensi komunikasi ke bawah, tenaga pemasar melakukan komunikasi dengan baik kepada setiap sekretarisnya yang berkaitan dengan tugas dan tanggung jawab yang diembannya. Pada dimensi komunikasi ke atas, dilihat bahwa tenaga pemasar dapat menyampaikan gagasan kepada atasan. Pada dimensi komunikasi horizontal, dapat dilihat dari hubungan yang harmonis antar tenaga pemasar yang sering memberikan saran dan masukan yang berhubungan dengan pekerjaan.

Berdasarkan keterangan di atas, pada total jawaban responden mengenai kualitas pelayanan yang dinilai dari dimensi; komuikasi ke bawah, komunikasi ke atas, komunikasi horizontal mendapatkan nilai rata-rata 3,89 dengan kriteria jawaban baik. Kemudian nilai rata-rata tertinggi sebesar 4,21 dengan kriteria jawaban sangat baik untuk dimensi komunikasi horizontal pada indikator berdiskusi dengan pegawai lain untuk memecahkan suatu masalah dalam pekerjaan. Sedangkan rata-rata nilai terendah sebesar 3,21 dengan kriteria jawaban cukup baik untuk dimensi komunikasi ke atas pada indikator menyampaikan keluhan kepada pimpinan. 
2. Gambaran Etos Kerja pada PT Prudential Life Assurance Prestasi Agency PS-1 Pematangsiantar

Salah satu faktor yang dapat mempengaruhi kinerja tenaga pemasar dalam melaksanakan pekerjaannya adalah budaya etos kerja. Etos kerja merupakan suatu sikap jiwa seseorang untuk melaksakan suatu pekerjaan dengan komitmen total dang tanggung jawab. Dalam hal ini, PT Prudential Life Assurance Prestasi Agency PS-1 Pematangsiantar membangun etos kerja yang baik kepada tenaga pemasarnya sebagai prasyarat mutlak yang harus ditumbuhkan dalam diri setiap tenaga pemasar. Adapun dimensi etos kerja pada PT Prudential Life Assurance Prestasi Agency PS-1 Pematangsiantar diantaranya kerja adalah rahmat, kerja adalah amanah, kerja adalah panggilan, kerja adalah aktualisasi, kerja adalah ibadah, kerja adalah seni, kerja adalah kehormatan, kerja adalah pelayanan.

Pada dimensi kerja adalah rahmat, dapat dilihat bahwa tenaga pemasar bekerja dengan tulus dan penuh rasa syukur. Pada dimensi kerja adalah amanah, dilihat bahwa tenaga pemasar dapat bekerja dengan penuh tanggung jawab. Pada dimensi kerja adalah panggilan, dilihat bahwa tenaga pemasar dapat bekerja dengan penuh integritas. Pada dimensi kerja adalah aktualisasi, dilihat bahwa tenaga pemasar bekerja dengan penuh semangat. Pada dimensi kerja adalah ibadah, dilihat bahwa tenaga pemasar dapat bekerja dengan serius dan mencintai pekerjaannya. Pada dimensi kerja adalah seni, dilihat bahwa tenaga pemasar dapat bekerja dengan penuh kreativitas. Pada dimensi kerja adalah kehormatan, dilihat bahwa tenaga pemasar dapat bekerja dengan tekun. Pada dimensi kerja adalah pelayanan, dilihat bahwa tenaga pemasar dapat bekerja dengan penuh kerendahan hati

Berdasarkan keterangan di atas, pada total jawaban responden mengenai kualitas pelayanan yang dinilai dari dimensi; kerja adalah rahmat, kerja adalah amanah, kerja adalah panggilan, kerja adalah aktualisas kerja adalah ibadah, kerja adalah seni, kerja adalah kehormatan, kerja adalah pelayanan mendapatkan nilai rata-rata 3,83 dengan kriteria jawaban baik. Kemudian nilai rata-rata tertinggi sebesar 4,05 dengan kriteria jawaban baik untuk dimensi kehormatan pada indikator mempunyai kehormatan untuk mau bekerja dengan penuh keunggulan. Sedangkan rata-rata nilai terendah sebesar 3,05 dengan kriteria jawaban cukup baik untuk dimensi kerja adalah rahmat pada indikator memiliki rahmat untuk patuh dalam bekerja.

\section{Gambaran Kinerja Tenaga Pemasar pada PT} Prudential Life Assurance Prestasi Agency PS1 Pematangsiantar

Kinerja pada organisasi merupakan jawaban dari berhasil atau tidaknya tujuan organisasi yang telah ditetapkan. Kinerja dapat ditingkatkan apabila adanya keseriusan dan ketekunan saat bekerja. Saat seringnya atasan tidak mengetahui betapa buruknya kinerja telah merosot sehingga intansi menghadapi krisis yang serius. Mengabaikan tanda-tanda persoalan mengakibatkan kinerja yang merosot sehingga organisasi tersebut akan menghadapi krisis yang serius.

Dalam mewujudkan keberhasilan organisasi, tenaga pemasar PT Prudential Life Assurance Prestasi Agency PS-1 Pematangsiantar berusaha semaksimal mungkin untuk meningkatkan kinerjanya. Adapun dimensi kinerja tenaga pemasar pada PT Prudential Life Assurance Prestasi Agency PS-1 Pematangsiantar terdiri dari kuantitas, kualitas, ketepatan waktu, kehadiran, kemampuan kerjasama. Kuantitas dapat dilihat ketika tenaga pemasar mampu menyelesaikan pekerjaan sesuai dengan target yang telah ditentukan. Kualitas dapat dilihat ketika tenaga pemasar mampu melaksanakan pekerjaan dengan penuh ketelitian.

Ketepatan waktu dapat dilihat ketika tenaga pemasar mampu memanfaatkan waktu bekerja dengan sebaik mungkin. Kehadiran dapat dilihat ketika tenaga pemasar selalu hadir dalam bekerja dan selalu bekerja dengan penuh waktu sesuai dengan yang telah ditetapkan. Kemampuan kerjasama dapat dilihat ketika tenaga pemasar mampu bersosialisasi dan saling membantu antar sesama tenaga pemasar lainnya.

Berdasarkan keterangan di atas, pada total jawaban responden mengenai kualitas pelayanan yang dinilai dari dimensi; kuantitas, kualitas, ketetapan waktu, kehadiran, kemampuan kerjasama mendapatkan nilai rata-rata 3,74 dengan kriteria jawaban baik. Kemudian nilai rata-rata tertinggi sebesar 4,25 dengan kriteria jawaban sangat baik untuk dimensi kemampuan kerja sama pada indikator indikator inisiatif dalam menyelesaikan pekerjaan. Sedangkan rata-rata nilai terendah sebesar 3,24 dengan kriteria jawaban cukup baik untuk dimensi ketepatan waktu pada indikator efesiensi waktu yang dilakukan dalam bekerja.

\section{1) Analisa Regresi Linear Berganda}

Fungsi dari analisis regresi adalah untuk melihat pengaruh yang terjadi di antara ketiga variabel. Selain itu analisis regresi juga berfungsi sebagai penunjuk arah hubungan yang terjadi antara variabel dependen dan variabel indenpenden. Untuk melihat apakah ada pengaruh komunikasi dan etos kerja terhadap kinerja tenaga pemasar pada PT Prudential Life Assurance Prestasi Agency Ps-1 Pematangsiantar

Tabel 17

Analisis Regresi Linier Berganda

\begin{tabular}{|c|c|c|c|}
\hline \multirow{2}{*}{ Model } & \multicolumn{2}{|c|}{$\begin{array}{c}\text { Unstandardized } \\
\text { Coefficients }\end{array}$} & $\begin{array}{c}\text { Standardized } \\
\text { Coefficients }\end{array}$ \\
\cline { 2 - 4 } & B & $\begin{array}{c}\text { Std. } \\
\text { Error }\end{array}$ & Beta \\
\hline (Constant) & $\mathbf{8 , 8 2 4}$ & 6,281 & \\
\hline
\end{tabular}




$\left[\begin{array}{ll|l|l|l}1 & \text { Komunikasi } & \mathbf{, 3 2 8} & , 158 & , 213 \\ & \text { Etos Kerja } & \mathbf{3 8 9} & , 073 & , 550 \\ \hline\end{array}\right.$

a. Dependent Variabel: Kinerja

Sumber: hasil pengolahan kuesioner dengan SPSS Versi 21 (2017).

Berdasarkan hasil pengolahan data pada tabel 16 diperoleh model persamaan $\hat{Y}=8,824+$ $0,328 \mathrm{X}_{1}+0,389 \mathrm{X}_{2}$. Artinya terdapat pengaruh yang positif antara komunikasi $\left(\mathrm{X}_{1}\right)$ dan etos kerja $\left(\mathrm{X}_{2}\right)$ terhadap kinerja (Y) pada PT Prudential Life Assurance Prestasi Agency PS-1 Pematangsiantar.

\section{2) Korelasi dan Koefisien Determinasi}

Untuk menghitung kekuatan hubungan kualitas pelayanan, fasilitas dan kepuasan konsumen, dilakukan melalui analisis korelasi dan koefisien determinasi dengan rumus sebagai berikut:

Tabel 18

Korelasi dan Koefisien Determinasi

\begin{tabular}{|l|c|r|r|r|}
\hline Model & $\mathbf{R}$ & $\boldsymbol{R}$ Square & $\begin{array}{c}\text { Adjusted } R \\
\text { Square }\end{array}$ & $\begin{array}{c}\text { Std. Error of the } \\
\text { Estimate }\end{array}$ \\
\hline 1 & $\mathbf{, 6 8 0}^{\mathrm{a}}$ & $\mathbf{4 6 3}$ &, 446 & 4,651 \\
\hline
\end{tabular}

a. Predictors: (Constant), Etos Kerja, Komunikasi

b. Dependent Variabel: Kinerja

Sumber: hasil pengolahan kuesioner dengan SPSS Versi 21 (2017).

Berdasarkan hasil penelitian pada tabel 18, diperoleh r sebesar 0,680, yang artinya terdapat hubungan yang kuat dan positif antara komunikasi dan etos kerja dengan kinerja tenaga pemasar pada PT Prudential Life Assurance Prestasi Agency Ps-1 Pematangsiantar

Berdasarkan tabel 18 selanjutnya diperoleh nilai koefisien determinasi $(\mathrm{R}$ Square $)=0,463$, artinya tinggi rendahnya kinerja (Y) di PT Prudential Life Assurance Prestasi Agency Ps-1 Pematangsiantar sebesar 46,3\% dapat dijelaskan oleh komunikasi (X1) dan etos kerja (X2), sedangkan sisanya $53,7 \%$ dipengaruhi oleh faktor lain seperi faktor kemampuan dan faktor motivasi dan faktor lain faktor kemampuan dan faktor motivasi dan faktor lain yang tidak dijelaskan dalam penelitian ini.

\section{3) Uji Hipotesis}

a) Uji Simultan (Uji F)

Uji $F$ digunakan untuk mengetahui apakah variabel bebas (komunikasi dan etos kerja) berpengaruh terhadap variabel terikat (kinerja) secara bersama-sama atau simultan. Yaitu dilakukan untuk menentukan diterima atau ditolaknya hipotesis. Jika tingkat signifikan dibawah 5\% atau $\mathrm{F}_{\text {hitung }}>\mathrm{F}_{\text {tabel }}$ maka $\mathrm{H}_{0}$ ditolak.

Tabel 19

Perkiraan Nilai F hitung

\begin{tabular}{|c|c|c|c|c|c|}
\hline \multirow{2}{*}{ Model } & $\begin{array}{c}\text { Sum of } \\
\text { Squares }\end{array}$ & Df & $\begin{array}{c}\text { Mean } \\
\text { Square }\end{array}$ & F & Sig. \\
\hline
\end{tabular}

\begin{tabular}{|l|l|r|l|l|l|}
\hline Regression & 1247.089 & 2 & 623.545 & $\mathbf{2 8 , 8 2 8}$ & $\mathbf{. 0 0 0}^{\mathbf{b}}$ \\
Residual & 1449.211 & 67 & 21.630 & & \\
Total & 2696.300 & 69 & & & \\
\hline
\end{tabular}

a. Dependent Variabel: Kinerja

b. Predictors: (Constant), Etos.Kerja, Komunikasi

Sumber: hasil pengolahan kuesioner dengan SPSS Versi 21 (2017)

Berdasarkan table 19 di atas diperoleh hasil $\mathrm{f}_{\text {hitung }}$ sebesar 28,828 , sedangkan $\mathrm{f}_{\text {tabel }}(0,05 ; 2$ vs 67$)$ sebesar 3,13 atau dengan signifikansi $0,000<0,05$, maka $\mathrm{H}_{0}$ ditolak, artinya komunikasi dan etos kerja berpengaruh positif dan signifikan terhadap kinerja pada PT Prudential Life Assurance Prestasi Agency Ps-1 Pematangsiantar.

b) Uji Parsial (Uji t)

Untuk menghasilkan suatu kesimpulan yang valid, maka harus dilakukan uji hipotesis. Pengujian ini dilakukan untuk menentukan diterima atau ditolaknya hipotesis, pengujian hipotesis dilakukan untuk mengetahui apakah variabel kualitas pelayanan dan fasilitas yang diuji berpengaruh terhadap kepuasan konsumen. Jika tingkat signifikansi dibawah $5 \%$ atau $\mathrm{t}_{\text {hitung }}>\mathrm{t}_{\text {tabel }}$ maka $\mathrm{H}_{0}$ ditolak.

Tabel 20

Perkiraan Nilai thitung

\begin{tabular}{|ll|c|c|}
\hline \multicolumn{1}{|c|}{ Model } & $\mathbf{t}$ & Sig. \\
\hline \multirow{2}{*}{1} & (Constant) & 1,405 &, 165 \\
& Kominikasi & $\mathbf{2 , 0 7 0}$ & $\mathbf{, 0 4 2}$ \\
& Etos Kerja & $\mathbf{5 , 3 7 5}$ & $\mathbf{, 0 0 0}$ \\
\hline
\end{tabular}

a. Dependent Variabel: Kepuasan Konsumen

Sumber: hasil perhitungan dengan SPSS versi 20.

Dari tabel 21 di atas diperoleh nilai

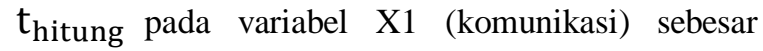
$2,070>\mathrm{t}_{\text {tabel }}$ dengan $\mathrm{df}=\mathrm{n}-\mathrm{k}-1 \quad(70-2-1=67)$ sebesar 1,996 atau taraf signifikansi 0,042 < alpha 0,05, maka $\mathrm{H}_{0}$ dtolak, artinya komunikasi berpengaruh positif dan signifikan terhadap kinerja pada PT Prudential Life Assurance Prestasi Agency Ps-1 Pematangsiantar.

Kemudian nilai $t_{\text {hitung pada variabel } \mathrm{X} 2}$ (fasilitas) sebesar 5,357 $>\mathrm{t}$ tabel dengan $\mathrm{df}=\mathrm{n}-\mathrm{k}-1$ $(70-2-1=67)$ sebesar 1,996 atau taraf signifikansi $0,000<$ alpha 0,05 , maka $\mathrm{H}_{0}$ ditolak, artinya etos kerja berpengaruh positif dan signifikan terhadap kinerja pada PT Prudential Life Assurance Prestasi Agency Ps-1 Pematangsiantar.

\section{Evaluasi}

a. Komunikasi pada PT Prudential Life Assurance Prestasi Agency PS-1 Pematangsiantar 
Berdasarkan hasil rekapitulasi penelitian, maka diperoleh hasil penelitian yang menyatakan bahwa k omunikasi pada PT Prudential Life Assurance Prestasi Agency PS-1 Pematangsiantar dapat dikatakan baik, hal ini dapat dilihat dari hasil kuesioner yang dibagikan kepada responden yang secara keseluruhan diperoleh nilai rata-rata 3,89 dengan kriteria jawaban baik.

Sedangkan pada dimensi komunikasi kebawah, pada indikator pimpinan memberikan motivasi kepada anda memperoleh rata-rata nilai 3,88 dengan kriteria jawaban baik, cara meningkatkannya adalah sebaiknya pimpinan menjalin komunikasi yang baik dengan tenaga pemasar seperti dengan cara mendengarkan dan mempertimbangkan ide-ide baru yang disampaikan oleh tenaga pemasar.

Pada dimensi komunikasi ke atas dengan indikator menyampikan keluhan terhadap pimpinan memperoleh nilai rata-rata sebesar 3,21 dengan kriteria jawaban cukup baik. Untuk meningkatkannya, sebaiknya tenaga pemasar lebih berani dan lebih terbuka lagi kepada pimpinan dalam menyampaikan keluhan yang disampaikan oleh nasabah. Pada indikator keterbukaan menyampaikan gagasan diperoleh nilai rata-rata sebesar 3,77 dengan kriteria jawaban baik. Cara meningkatkannya adalah tenaga pemasar sebaiknya melakukan pendekatan terhadap pimpinan agar mudah menyampaikan gagasan demi kebaikan bersama. Selanjutnya pada indikator menginformasikan laporan setelah melakukan pekerjaan diperoleh nilai rata-rata sebesar 3,81 dengan kriteria jawaban baik. Untuk mengatasinya, sebaiknya atasan mengkomunikasikan hasil laporan secara rutin setidaknya dua kali dalam setahun, atasan memberikan penghargaan yang pantas kepada tenaga pemasar yang hasil laporannya sangat baik.

Dari evaluasi komunikasi di atas dapat diambil kesimpulan jika semua hal-hal di atas sudah berada pada kriteria jawaban baik. Dengan demikian bahwa komunikasi organisasi yang ada pada PT Prudential Life Assurance Prestasi Agency PS-1 Pematangsiantar sudah baik, namun hubungan antara atasan ke bawahan dan sesama rekan kerja sebaiknya di jaga dan terus tingkatkan agar tidak timbul permasalahan yang menghambat tujuan dari intansi

\section{b. Etos Kerja pada PT Prudential Life Assurance Prestasi Agency PS-1 Pematangsiantar}

Berdasarkan hasil rekapitulasi penelitian, maka diperoleh hasil penelitian yang menyatakan etos kerja pada PT Prudential Life Assurance Prestasi Agency PS-1 Pematangsiantar sudah baik. Hal ini dapat dilihat dari hasil kuesioner yang dibagikan kepada responden yang secara keseluruhan diperoleh nilai rata-rata 3,83 dengan kriteria jawaban baik. Akan tetapi masih terdapat beberapa indikator yang memperoleh nilai dibawah rata-rata, yang pertama pada dimensi kerja adalah rahmat dengan indikator tenaga pemasar memiliki rahmat untuk mau bekerja dengan tulus diperoleh nilai rata-rata sebesar 3,75 dengan kriteria jawaban baik, untuk meningkatkannya sebaiknya pimpinan memberikan penghargaan kepada tenaga pemasar agar meningkatkan ketulusan dalam bekerja. Pada dimensi kerja adalah rahmat dengan indikator rahmat untuk bekerja dengan penuh syukur dalam bekerja diperoleh nilai rata-rata sebesar 3,78 dengan kriteria jawaban baik, untuk mengatasinya sebaiknya tenaga pemasar lebih menyukuri yang dikerjakannya dan yang diperolehnya. Pada dimensi kerja adalah rahmat dengan indikator rahmat untuk patuh dalam bekerja diperoleh nilai rata-rata sebesar 3,05 dengan kriteria jawaban cukup baik, untuk meningkatkannya tenaga pemasar harusnya lebih patuh dengan arahan yang diberikan pimpinan agar pekerjaan berjalan dengan baik.

Pada dimensi kerja adalah amanah dengan indikator berkomitmen diperoleh nilai rata-rata sebesar 3,17 dengan kriteria jawaban cukup baik, untuk meningkatkannya adanya kerja keras demi tercapainya tujuan dari tenaga pemasar, seperti lebih giat dalam mencari nasabah. Pada dimensi kerja adalah amanah dengan indikator amanah untuk bekerja penuh tanggungjawab diperoleh nilai ratarata sebesar 3,64 dengan kriteria jawaban baik, hal ini dapat diatasi dengan cara mengoptimalkan rasa tanggungjawab pada pekerjaan dan menerima resiko, seperti mengahadapi keluhan nasabah. Pada dimensi kerja adalah amanah dengan indikator memiliki amanah bekerja dengan benar diperoleh nilai ratarata sebesar 3,77 dengan kriteria jawaban baik, untuk mengatasinya pimpinan selalu memberikan contoh yang baik dalam bekerja kepada tenaga pemasar.

Pada dimensi kerja adalah panggilan untuk indikator memiliki panggilan untuk mau bekerja dengan tuntas diperoleh nilai rata-rata sebesar 3,71 dengan kriteria jawaban baik, untuk mengatasinya tenaga pemasar hendaknya mampu menyelesaikan pekerjaanya dengan baik sebelum menerima pekerjaan baru. Pada dimensi kerja adalah panggilan dengan indikator memiliki panggilan untuk mau bekerja dengan penuh integritas diperoleh nilai ratarata sebesar 3,77 dengan kriteria jawaban baik, untuk meningkatkannya tenaga pemasar bekerja secara konsisten sesuai dengan aturan-aturan yang ada, seperti tidak lari dari tanggungjawab dalam bekerja sehingga memiliki integritas yang baik untuk menyelesaikannya.

Selanjutnya pada dimensi kerja adalah panggilan dengan indikator panggilan untuk bekerja dengan segenap hati diperoleh nilai rata-rata sebesar 3,38 dengan kriteria jawaban cukup baik, untuk mengatasinya tenaga pemasar harus menintai pekerjaannya dengan segenap hati agar pekerjaan apapun yang dikerjakanya bekerja dengan baik. Pada dimensi kerja adalah aktualisasi dengan indikator memiliki aktualisasi untuk menyelesaikan tugas dalam bekerja diperoleh nilai rata-rata sebesar 3,82 dengan kriteria jawaban baik, untuk mengatasinya tenaga pemasar menunjukkan kemampuan daridalam dirinya bahwa pegawai dapa menyelesaikan pekerjaan dengan baik. Pada dimensi kerja adalah 
aktualisasi dengan indikator memiliki aktualisasi untuk bekerja dengan penuh semangat diperoleh nilai rata-rata sebesar 3,80 dengan kriteria jawaban baik, untuk mengoptimalkannya tenaga pemasar mampu mendorong dirinya untuk bertindak dan meraih kinerja yang optimal dengan penuh semangat untuk tujuan hasil yang baik.

Selanjutnya untuk dimensi kerja adalah aktualisai dengan indikator memiliki aktualisasi dalam mencapai target kerja diperoleh nilai rata-rata sebesar 3,78 dengan kriteria jawaban baik, untuk meningkatkannya tenaga pemasar harus bekerja dengan gigih, pantang menyerah untuk mencapai hasil yang baik. Pada dimensi kerja adalah kehormatan dengan indikator cara dalam meningkatkan wibawa diperoleh nilai rata-rata sebesar 3,31 dengan kriteria jawaban cukup baik, untuk mengatasinya tenaga pemasar yang bekerja dengan baik sebaiknya mampu mempengaruhi tenaga pemasar lain untuk bekerja dengan baik

Dari evaluasi etos kerja di atas dapat ditarik kesimpulan jika semua hal-hal diatas sudah berada pada kriteria jawaban baik. Dengan adanya perbakan-perbaikan dalam dimensi etos kerja diharapkan tenaga pemasar pada PT Prudential Life Assurance Prestasi Agency PS-1 Pematangsiantar harus optimis dalam bekerja dan berorientasi untuk kedepan dengan kerja kerasa, disiplin, tekun, ulet, bersungguh-sungguh, ikhlas, dan penuh tanggung jawab dalam bekerja sehingga tujuan organisasi tercapai.

\section{c. Kinerja Tenaga Pemasar PT Prudential Life Assurance Prestasi Agency PS-1 \\ Pematangsiantar}

Berdasarkan hasil rekapitulasi penelitian, maka diperoleh hasil penelitian yang menyatakan bahwa kinerja yang terdapat PT Prudential Life Assurance Prestasi Agency Ps-1 Pematangsiantar memiliki rata-rata secara keseluruhan sebesar 3,74 dengan kriteria jawaban baik. Namun masih terdapat beberapa indikator yang masih berada di bawah ratarata indikator lain, yang pertama pada dimensi kuantitas untuk indikator tanggung jawab hasil kerja diperoleh nilai rata-rata sebesar 3,67 dengan kriteria jawaban baik, untuk mengoptimalkannya tenaga pemasar harus mampu mempertanggungjawabkan hasil pekerjaanya dengan baik, yaitu bekerja dengan jujur. Pada dimensi kuantitas dengan indikator pencapaian target kerja diperoleh nilai rata-rata sebesar 3,27 dengan kriteria jawaban cukup baik, untuk meningkatkannya para tenaga pemasar harus bekerja lebih giat dalam mencapai target, seperti terus bergiat mencari nasabah. Pada dimensi kuantitas dengan indikator tingkat penyelesaian pekerjaan diperoleh nilai rata-rata sebesar 3,70 dengan kriteria jawaban baik, untuk mengatasinya tenaga pemasar harus menyelesaikan pekerjaanya pekerjaan sebelum menerima pekerjaan yang lain.

Pada dimensi kualitas untuk indikator ketelitian dalam bekerja diperoleh nilai rata-rata sebesar 3,64 dengan kriteria jawaban baik, untuk mengoptimalkanya tenaga pemasar harus hati-hati dalam bekerja. Pada dimensi ketepatan waktu untuk indikator efisien waktu yang dilakukan dalam bekerja diperoleh nilai rata-rata sebesar 3,24 dengan kriteria jawaban cukup baik, untuk mengatasinya dapat menyesuakian waktunya dalam bekerja. Pada dimensi ketepatan waktu dengan indikator penyelesaian bekerja dengan tenggang waktu diperoleh nilai rata-rata sebesar 3,65 dengan kriteria jawaban baik, untuk meningkatkannya tenaga pemasar memiliki kemampuan menyelesaikan pekerjaanya dengan tenggang waktu yang telah di tentukan. Pada dimensi ketepatan waktu dengan indikator kehadiran dari waktu yangt diharapkan di peroleh nilai rata-rata sebesar 3,72 dengan kriteria jawaban baik, untuk mengatasinya tenaga pemasar harus lebih tepat waktu untuk memulai bekerja dari waktu yang telah ditetapkan.

Pada dimensi kehadiran untuk indikator kehadiran tenaga pemasar ditempat kerja dalam memulai aktivitas di peroleh nilai rata-rata sebesar 3,68 dengan kriteria jawaban baik untuk meningkatkannya tenaga pemasar memiliki jiwa semangat untuk memulai aktivitas yang akan dikerjakannya.

Dari evaluasi etos kerja di atas dapat ditarik kesimpulan jika semua hal-hal diatas sudah berada pada kriteria jawaban baik. Namun dalam hal ini peningkatan kinerja perlu dilakukan oleh tenaga pemasar. Tenaga pemasar harus memiliki semangat kerja yang tinggi agar kinerjanya semakin mningkat. Pihak perusahaan perlu memperhatikan kinerja tenaga pemasar, melakukan pembinaan secara formal yang menyangkut indikator-indikator yang dianggap belum optimal. Perusahaan juga harus memberikan motivasi kepada tenaga pemasar, memberikan pelayanan dan pimpinan harus lebih mampu melakukan pendekatan dengan tenaga pemasarnya agar tercipta hubungan yang kuat untuk mencapai tujuan perusahaan dengan meningkatkan kinerja tenaga pemasar akan mampu mendorong perusahaan untuk mencapai tujuan organisasinya

\section{KESIMPULAN DAN SARAN}

\section{Kesimpulan}

a. Hasil analisis regresi linear berganda dihitung diperoleh model persamaan $\hat{\mathrm{Y}}=8,824+0,328 \mathrm{X}_{1}$ $+0,389 \mathrm{X}_{2}$, artinya, terdapat pengaruh yang positif antara variabel komunikasi dan variabel etos kerja variabel kinerja tenaga pemasar pada PT Prudential Life Assurance Prestasi Agency PS-1 Pematangsiantar.

b. Hasil analisis korelasi dan determinasi nilai $r=0,680$, yang artinya terdapat hubungan yang kuat dan positif antara variabel komunikasi dan etos kerja dengan kinerja tenaga pemasar pada PT Prudential Life Assurance Prestasi Agency PS-1 Pematangsiantar. kemudian diperoleh nilai koefisien determinasi (R Squer) $=0,463$, artinya baik tidaknya kinerja tenaga pemasar pada PT Prudential Life Assurance Prestasi Agency PS-1 Pematangsiantar sebesar $46,3 \%$ dapat dijelaskan 
oleh komunikasi dan etos kerja selebihnya 53,7\% dijelaskan oleh faktor seperti lingkungan kerja dan sebagainya yang tidak dijelaskan dalam penelitian ini.

c. Hasil pengujian hipotesis secara simultan dengan uji $\mathrm{F}$, terdapat pengaruh positif dan signifikan antara komunikasi dan etos kerja terhadap kinerja, nilai $F_{\text {hitung }}$ sebesar 28,828 sedangakan $F_{\text {tabel }}$ dengan $(0,05: 2$ vs 67$)$ sebesar 3,13 maka $\mathrm{H}_{0}$ ditolak, artinya komunikasi dan etos kerja berpengaruh positif dan signifikan terhadap kinerja tenaga pemasar pada PT Prudential Life Assurance Prestasi Agency PS-1 Pematangsiantar.

d. Hasil pengujian Hipotesis secara parsial dengan uji $t$, terdapat pengaruh yang positif dan signifikan antara komunikasi dan etos kerja terhadap kinerja, diperoleh nilai thitung pada variabel $\mathrm{X}_{1}$ (komunikasi) sebesar 2,070 > dari $\mathrm{t}_{\text {tabel }}$ dengan $\mathrm{df}=\mathrm{n}-\mathrm{k}-1 \quad(70-2-1=67)$ sebesar 1,99601 atau taraf signifikansi $0,042<$ alpha 0,05, maka $\mathrm{H}_{0}$ ditolak, artinya komunikasi berpengaruh positif dan signifikan terhadap kinerja tenaga pemasar pada PT Prudential Life Assurance Prestasi Agency PS-1 Pematangsiantar. Kemudian nilai thitung pada variabel $\mathrm{X}_{2}$ (etos kerja) sebesar 5,357> dari $\mathrm{t}_{\text {tabel }}$ dengan $\mathrm{df}=\mathrm{n}-\mathrm{k}-1 \quad(70-2-1=67)$ sebesar 1,99601 atau taraf signifikansi $0,000<$ alpha 0,05 , maka $\mathrm{H}_{0}$ ditolak, artinya etos kerja berpengaruh positif dan signifikan terhadap kinerja tenaga pemasar pada PT Prudential Life Assurance Prestasi Agency PS-1 Pematangsiantar.

\section{Saran}

a. Untuk meningkatkan komunikasi pada PT Prudential Life Assurance Prestasi Agency PS-1 Pematangsiantar, sebaiknya tenaga pemasar lebih berani dan lebih terbuka lagi kepada pimpinan dalam menyampaikan keluhan yang disampaikan oleh nasabah.

b. Untuk meningkatkan etos kerja pada PT Prudential Life Assurance Prestasi Agency PS-1 Pematangsiantar tenaga pemasar harusnya lebih patuh dengan arahan yang diberikan pimpinan agar pekerjaan berjalan dengan baik. Dengan memberikan arahan yang benar dan cara yang benar ini akan membantu tenaga pemasar lebih optimal.

c. Untuk mengoptimalkan kinerja tenaga pemasar pada PT Prudential Life Assurance Prestasi Agency PS-1 Pematangsiantar sebaiknya para tenaga pemasar harus bekerja lebih giat dalam mencapai target, seperti terus bergiat mencari nasabah, mengadakan pertemuan terhadap nasabah agar mendapatkan hasil yang lebih baik lagi.

d. Sehubungan dengan penelitian ini, penulis menyadari bahwa banyak keterbatasanketerbatasan yang ada pada penulis sehingga masih terdapat kelemahan-kelemahan yang belum dapat diungkapkan mengenai variabel- variabel yang mempengaruhi kinerja tenaga. Untuk itu penulis menyarankan kepeda penelitian selanjutnya agar lebih banyak memasukkan variabel-variabel penelitian lain yang tidak dibahas di dalam penelitian ini.

\section{E. DAFTAR PUSTAKA}

Anoraga, Pandji. 2001. Psikologi Kerja. Jakarta: Penerbit Rineka Cipta.

Anoraga. 2009. Manajemen Bisnis. Jakarta: Rineka Cipta.

Anwar, Muhammad Sohali, Muhammad Aslam. Dan Muhammad Rashid. 2011. Temporary job and its Impact on Employee performance. Lohare : university of lohareislamabad Campus. International Journal.

Arif, sehfudin. 2011. Pengaruh Gaya Kepemimpinan, Komunikasi Organisasi, dan Motivasi Kerja Terhadap Kinerja Karyawan pada PT Bank Tabungan Pensiun Nasional Cabang. Semarang: Universitas Diponegoro. Skripsi

Bangun, Wilson. 2012. Manajemen Sumber Daya Manusia. Jakarta: Erlangga.

Cherringtong 2000, Manajemen, Edisi Kedua, Cetakan Kedelapanbelas, Bogor: Grafika Mardi Yuana.

Daft, Richard L. 2007. Manajemen, Buku 1, Edisi 6. Jakarta: Salemba Empat.

Dessler, Gary. 2007. Manajemen Sumber Daya Manusia. Jilid 2, Edisi 10. Jakarta: PT. Indeks.

Dessler. G. 2004. Manajemen Sumber Daya Manusia. Jakarta: Pren hallindo.

Dewi, Sutrisna. 2007. Komunikasi Bisnis. Yogyakarta: Andi.

Dharma, Agus. 2001. Manajemen Sumber Daya Manusia. Jakarta: Erlangga.

Febriana, Maya puji. 2009. Pengaruh Etos Kerja Islami terhadap Kinerja Karyawan. Semarang: Institut Agama Islam Negeri Walisongo. Skripsi.

Griffin, Ricky W. 2004. Manajemen. Edisi ketuju. Jakarta: Erlangga.

Gustiandri, Diskayatika. 2012. Pengaruh iklim komunikasi organisasi terhadap kinerja pegawai di Direktorat Jenderal Pajak Pratama Kantor Pelayanan Pajak. Serang: Universitas Serang Raya Skripsi. Diakses Tahun 2017. 
Ghozali, Imam. 2015. Aplikasi dan Analisis Multivariate Dengan Program SPSS 21. Cetakan VIII, Edisi 8. Semarang: Badan Penerbit UNDIP.

Kuswanto, M. Maret 2010. Pengaruh Kepemimpinan dan Komunikasi Terhadap Kinerja Karyawan Kaltim POS Samarinda. Jurnal Exsis. Volume 6, No.1,http://www.docsengine.com?/pdf//jurnal-komunikasi-organisasiterhadap-kinerja karyawan.html,20 Mei 2016. Diakses Tahun 2017.

Luthans, Fred. 2006. Perilaku Organisasi. Yogyakarta: Penerbit: Andi.

Mangkunegara, Anwar Prabu. 2009. Evaluasi Kinerja Sumber Daya Manusia. Bandung: Penerbit Rafika Aditama.

Mathis, Robert L and John H. Jackson. 2006. Human Resource Management. Edisi 10. Jakarta:Salemba Empat.

........, 2011. Manajemen Sumber Daya Manusia. Edisi X. Jakarta: Salemba Empat.

Mondy, R. Wayne. 2008. Manajemen Sumber Daya Manusia; Edisi X, Jilid 1. Jakarta: Erlangga.

Petty, Gregory. 2003. Etos Kerja Profesional. Terjemahan. Jakarta: Institut Darma Mahardika.

Purwanto, Djoko. 2003. Komunikasi Bisnis. Edisi kedua, Jakarta: Erlangga.

Rivai, veithzal. 2004. Manajemen Sumber Daya Manusia untuk Perusahaan. Jakarta: Raja Grafindo Persada.

Robbins, Stephen. 2006. Perilaku Organisasi, Edisi kesepuluh. Jakarta: Indeks Prenhallindo.

Robbins, Stephen P. dan Mary Coulter. 2010. Jilid. Manajemen; Edisi X, Jakarta: Erlangga.

2010. Manajemen. jilid 2, Edisi Keduabelas. Jakarta: Erlangga.

Robbins, Stephen P dan Timothy A Judge. 2008. Perilaku Organisasi. Jakarta: Salemba Empat.

Sekarningtyas, Dyah Ayu. 2011. Analisis Pengaruh Komunikasi dan Kecerdasan Emosional terhadap Kinerja Karyawan pada Dinas Perhubungan, Komunikasi, dan
Informatika Kab.Pemalang, Semarang: Universitas Diponegoro, Skripsi. Diakses Tahun 2017.

Sinamo, Jansen. 2005. Delapan Etos Kerja Profesional: Navigator Anda Menuju Sukses. Bogor: Grafika Mardi Yuana.

Solihin, Ismail. 2010. Pengantar Manajemen. Jakarta: Penerbit Erlangga.

Sugiyono. 2010. Metode Penelitian Kuantitatif Kualitatif dan R\&B. Bandung: Alfabeta.

Sukardewi, Nyoman,et. all.2013. Kontribusi Adversity Quotient (AQ) Etos Kerja dan Budaya Organisasi terhadap Kinerja.

Sutrisno, Edy. 2009. Manajemen Sumber Daya Manusia. Cetakan 1. Jakarta: Kencana Pernada Media Group.

Sutrisno, Edy. 2011. Manajemen Sumber Daya Manusia. Edisi 1. jakarta: Kencana.

Tasmara, Toto. 2002. Membangun Etos Kerja Islam, Jakarta: GemaInsani Press.

Wibowo. 2007. Manajemen Kinerja. Edisi Ketiga. Jakarta: Rajawali Pers. 